\title{
KARAKTERISIK KEKUATAN KOMPOSIT SERAT DAUN NANAS DENGAN VARIASI PANJANG SERAT
}

\author{
Supriyanto $^{1)}$, Jimin $^{2)}$ \\ 1),2) Jurusan Teknik Mesin Fakultas Teknik Universitas Janabadra Yogyakarta \\ E-mail: ${ }^{1)}$ supriyanto@ janabadra.ac.id
}

\begin{abstract}
Abstrak
Penggunaan material logam memiliki peranan yang sangat besar dalam perkembangan teknologi saat ini, terutama di dunia industri maupun otomotif, salah satu yang hal yang menjadi perhatian adalah pemilihan jenis dan kualitas bahan baku material untuk pembuatan komposit kendaraan. Beradasarkan data Badan Pusat Statik (BPS), rata-rata produksi nanas di Indonesia adalah 1,5 juta ton/hari. Melihat banyaknya produksi tanaman nanas pertahun, tentunya daun nanas berpontesi besar untuk menjadi limbah. Untuk itulah penelitian ini berinisiatif untuk memanfaatkan serat daun nanas Peneliatian ini bertujuan untuk mendapatkan nilai kekuatan uji Tarik dan uji Impack komposit serat daun nanas sebagai bahan pembuatan bumper mobil. Komposisi komposit serat daun nanas yaitu $40 \%$ serat daun nanas dan $60 \%$ resin. Resin yang digunakan adalah resin polyester, masing-masing spesiemen dibuat 3 benda untuk pengujian dari setiap varisi panjang serat $50 \mathrm{~mm}, 100 \mathrm{~mm}, 150 \mathrm{~mm}$ sehingga terdapat 12 spesimen pengujian untuk uji tarik dan uji impack. Berdasarkan pengujian sifat mekanik komposit serat daun nanas didapatkan nilai tegangan dan regangan tarik tertinggi adalah komposit dengan panjang serat $150 \mathrm{~mm}$ dengan nilai tegangan tarik sebesar 15,66 Mpa dan regangan $0,53 \%$ sedangkan sifat mekanik komposit serat daun nanas didapakan nilai tertinggi dengan panjang serat $100 \mathrm{~mm}$ dengan energi impack 11,23 joule dan kekuatan impack $0,145 \mathrm{j} / \mathrm{mm} 2$. Dari nilai yang didapatkan dari pengujiant tarik masing-masing panjang serat masih bekum bisa menyentuh nilai murni kekuatan matriks dengan tegangan tarik sebesar 31,63 Mpa. Dari hasil nilai yang didapat komposit serat daun nanas, memiliki nilai di atas standar JIS A5905-2003 bumper mobil.
\end{abstract}

Kata Kunci: Komposit, Serat Daun Nanas, Uji Tarik, Uji Impack.

\section{Abstract}

Based on data from the Central Statistics Agency (BPS), the average pineapple production in Indonesia is 1.5 million tons/day. Seeing the large production of pineapple plants per year, of course, pineapple leaves have great potential to become waste. For this reason, this study took the initiative to utilize pineapple leaf fiber. This study aims to obtain the value of the tensile strength test and Impack test of pineapple leaf fiber composites as a material for making car bumpers. The composite composition of pineapple leaf fiber is $40 \%$ pineapple leaf fiber and $60 \%$ resin. The resin used is polyester resin, each specimen is made of 3 objects for testing from each fiber length variation of $50 \mathrm{~mm}, 100 \mathrm{~mm}, 150 \mathrm{~mm}$ so that there are 12 test specimens for tensile tests and impack tests. Based on the testing of the mechanical properties of the pineapple leaf fiber composite, the highest tensile stress and strain values were found to be a composite with a fiber length of $150 \mathrm{~mm}$ with a tensile stress value of 15.66 Mpa and a strain of 0.53\%, while the mechanical properties of a pineapple leaf fiber composite obtained the highest value with a length of fiber. $100 \mathrm{~mm}$ with an impact energy of 11.23 joules and an impact strength of $0.145 \mathrm{j} / \mathrm{mm} 2$. From the value 
obtained from the tensile test, each fiber length still cannot touch the pure value of the matrix strength with a tensile stress of $31.63 \mathrm{Mpa}$. From the results obtained, the pineapple leaf fiber composite has a value above the standard JIS A5905-2003 car bumper.

Keywords: Composite, Pineapple Leaf Fiber, Tensile Test, Impack test

\section{PENDAHULUAN}

Ilmu pengetahuan dan teknologi di era modern mengalami perkembangan semakin pesat. Perkembangan tersebut meliputi di berbagai bidang, diantaranya otomotif industri, telekomunikasi, kesehatan, elektronika dan sebagainya. Penggunaan material logam memiliki peranan yang sangat besar dalam perkembangan teknologi saat ini, terutama di dunia industri maupun otomotif. Akan tetapi material logam tersebut merupakan sumber daya alam yang tidak dapat diperbarui sehingga para peneliti terus mengembangkan inovasi menciptakan suatu produk yang terbuat dari material yang dapat diperbarui, karena material-material yang merupakan sumber daya alam yang tidak dapat diperbarui jika digunakan secara terus menurus akanhabis. Dengan semakin berkembangnya inovasi dalam pembuatan suatu produk yang menggunakan material yang berasal dari sumber daya alam yang dapat diperbarui diharapkan akan mempermudah proses pembuatannya, ramah lingkungan, dan dapat menghemat biaya produksi namun tetap menghasilkan suatu produk yang berkualitas.

Pada beberapa tahun terakhir, kecenderungan perkembangan material komposit bergeser pada penggunaan serat alam kembali back to nature sebagai pengganti serat sintetik. Hal ini didukung oleh beberapa keunggulan yang dimiliki oleh serat alam, diantaranya adalah massa jenisnya rendah, terbarukan, produksi memerlukan energi yang rendah, proses lebih ramah, serta mempunyai sifat insulasi panas dan akustik yang baik [1].

Tanaman nanas (Ananas cosmosus) termasuk famili Bromeliaceae merupakan tumbuhan tropis dan subtropis yang banyak terdapat di Filipina, Brasil, Hawai, India dan Indonesia. Di Indonesia tanaman tersebut terdapat antara lain di Subang, Majalengka, Purwakarta, Purbalingga, Bengkulu, Lampung dan Palembang, yang merupakan salah satu sumber daya alam yang cukup berpotensi.

Dalam makalah ini, membahas tentang komposit serat daun nanas dengan serat 
komposit berpenguat serat daun nanas dengan arah serat lurus. Pilihan metode serat lurus karena menurut penelitian sebelumnya serabut lurus memiliki nilai kekuatan tarik dan impak yang cukup tinggi serta cara pembuatannya yang lebih mudah dan tampak elegan dibandingkan serabut acak. Dengan adanya variasi panjang serat $50 \mathrm{~mm}, 100 \mathrm{~mm}, 150 \mathrm{~mm}$ perlakuan

Material komposit merupakan gabungan antara dua atau lebih bahan yang memiliki jumlah sifat yang tidak mungkin dimiliki oleh masing- masing komponennya yang kemudian disusun secara kombinasi simetrik untuk memperoleh sifat tertentu. Dapat juga didefinisikan kombinasi antara dua material atau lebih dalam skala makroskopik yang berbeda bentuknya komposisi kimia dan tidak saling melarutkan antara materialnya dimana material yang satu berfungsi sebagai material penguat dan material yang lainnya sebagai pengikat untuk menjaga kesatuan unsur-unsurnya :

a. Penguat reinforcement, yang mempunyai sifat kurang ulet tapi lebih rigiditas serta lebih kuat, yang digunakan adalah serat alam.

b. Metrik, umumnya lebih ulet tetapi mempunyai kekuatan rigiditas lebih rendah. Nanas.

Nanas merupakan buah buahan yang cukup populer dengan rasa buahnya yang manis, dengan bentuk yang khas, tanaman ini termasuk family bromeliaceace yang tersebar diseluruh dunia. Tanaman nanas mempunyai nama ilmiah Ananas Cosmosus. Pada umumya termasuk jenis tanaman semusim. Menurut sejarah tanaman ini berasal dari Brazilla dan dibawa ke Indonesia oleh para pelaut spanyol dan portugis sekitar tahun 1599.

Di Indonesia tanaman tersebut sudah banyak dibudidayakan, terutama di pulau jawa dan sumatera yang diantaranya terdapat didaerah Subang, Majalengka, Purwakarta, Purbalingga, Bengkulu, Lampung, Pekanbaru, dan Palembang, yang merupakan salah satu sumber daya alam yang cukup berpotensi. Tanaman nanas akan di bongkar setelah dua kali atau tiga kali panen untuk diganti tanaman baru. Oleh karna itu, penggunaan daun nanas terus dikembangkan sehingga cukup potensi untuk dimanfaatkan sebagai produk yang dapat memberikan nilai tambah[2]. 


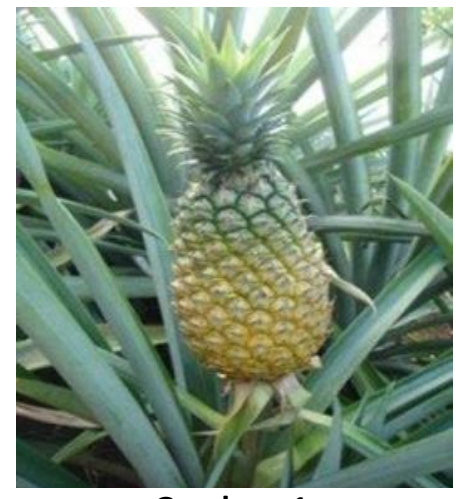

Gambar 1

Klasifikasi ilmiah atau taksonomi dari nanas adalah sebagai berikut:

Kingdom : Plastae (tumbuh-tumbuhan)

Devisi $\quad$ : Spermatophyta (tumbuhan berbiji)

Sub-division : Angiospermae (berbiji tertutup)

Kelas : Dicotyledonae

Sub-class : Magnoliales

Ordo : Annonales

Family : Annonacceac

Genus : Annona

Species : Comosus

Komposisi atau kandungan kimia dari serat daun nanas adalah ; selulosa, liginin, pektin, lemak dan wax, abu dan zat-zat lain (protein dan asam organic lainnya). Menurut Jayanudin (2009), terdapat 69, 5 - 71,5\% selulosa dalam serat daun nanas[3].

Kekutan dan modulus tarik tertinggi komposit serat nanas-nanasan -unsatuted polyster (UPRs) terjadi pada $\mathrm{Vr}=42,26 \%$, yaitu $153,39 \mathrm{MPa}$ dan 20,77 $\mathrm{GPa}$. Secara teoritis pada $\mathrm{Vr}=53,65 \%$, kekuatan dan modulus tarik komposit lebih tinggi[4]. Pengujian Kekuatan tarik, bending dan impak terhadap komposit dengan serat glass 3 layer dalam bentuk chopped strand dengan berat 300 gram/m2 yang dilakukan oleh Yanuar dan Diharjo (2002) diperoleh kekuatan Tarik 67,118 MPa, kekuatan bending 175,25 MPa dan Kekuatan Impaknya 0,045 $\mathrm{J} / \mathrm{mm} 2[5]$.

2. METODE PENELITIAN

a. Alat Dan Bahan

1) Uji Tarik

2) Uji Impack 

3) Cetakan kaca
4) Gelas pengukur
5) Timbangan.

b. Bahan - bahan Yang Digunakan

1) Serat nanas

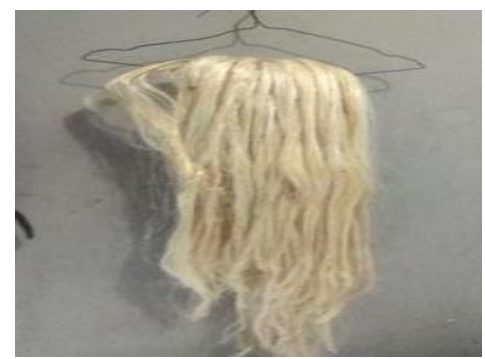

Gambar 2. Serat Nanas (Sumber: Dokumen pribadi)

Pemisahan atau pengambilan serat nanas dari daunnya dapat dilakukan dengan dua cara yaitu dengan cara manual dan dan cara mekanik, proses pemisahan yang di pilih dalam penelitian ini menggunakan cara manual, yang dapat di lakukan sebagai berikut:

a) Siapakan daun nanas yang sudah di sortir dengan kuliatas terbaik tidak cacat dan tidak kering dan panjang daun nanas di potong sama panjang siapakan sendok atau pisau tumpul.

b) Cuci daun nanas dengan air untuk menghilangakan kotoran yang menempel pada daun nanas

c) Kemudian kerok serat nanas menggunakan sendok / pisau tumpul untuk memisahkan zat zat yang masih menempel.

d) Kemudian cuci serat nanas dengan air bersih setelah proses pengerokan sampai serat bersih dari zat zat yang menempel.

e) Jemur serat nanas di terik matahari sampai kering, penjemuran ini memerlukan waktu kurang lebih 2 hari jika panas.

f) Setelah kering serat nanas siap di gunakan.

2) Resin Polyester

3) Katalis

4) $\mathrm{NaOH}$

5) Mirror Glaze

c. Proses Pembuatan Komposit 
Pada proses pembuatan benda uji di butuhkan minimal 3 benda uji dari setiap variasi yaitu, komposit tanpa serat, panjang serat $50 \mathrm{~mm}$, Panjang serat 100 $\mathrm{mm}$, Panjang serat $150 \mathrm{~mm}$ sehingga benda uji berjumlah 12 spesimen. Langkah-langkah proses pembuatan benda uji komposit adalah sebagai berikut:

1) Bersihkan serat nanas terlebih dahulu dengan menggunakan air bersih untuk menghilangkan kotoran pada serat nanas dan, kemudian rendam serat nanas dengan 25 gr NaOH lalu larutakan $\mathrm{NaOH}$ sebanyak $500 \mathrm{ml}$ air bersih.

2) Rendam serat nanas dengan $\mathrm{NaOH}$ selama 1 jam.

3) Bersihkan serat nanas dari redaman $\mathrm{NaOH}$ dengan air bersih yang mengalir

4) Jemur serat nanas dibawah terik matahari sekitar 2-3 hari sampai kadar airnya berkurang.

5) Setelah serat nanas kering lalu potong dengan ukuran $50 \mathrm{~mm}, 100 \mathrm{~mm}$, $150 \mathrm{~mm}$, untuk Uji Tarik dan Uji Impak, berat seratnya sendiri untuk Uji Tarik 102 gr dan untuk Uji Impak 6 gr.

6) Bersihkan cetakan, lalu lapisi mirror glaze pada cetakan yang akan digunakan bertujuan agar mudah dilepas dari cetakan saat sudah kering.

7) Proses pencampuran, campurkan resin sebanyak 59.5\% dan katalis 0,5\% kemudian aduk secara merata.

8) Tuangkan campuran resin dan katalis, lalu ratakan.

9) Setelah rata letakan resin kedalam cetakan hingga rata lalu tutup atasnya dengan kaca yang sudah dilapisi mirror glaze agar komposit setelah kering tidak melengkung.

10) Tunggu sekitar 24 jam agar komposit mongering merata.

11) Setelah kering lepas komposit dari cetakan lalu potong sesuai standar yang di tentukan.

12) Komposit siap untuk Uji Tarik dan Uji Impak 
3. HASIL DAN PEMBAHASAN

a. Pengujian Tarik

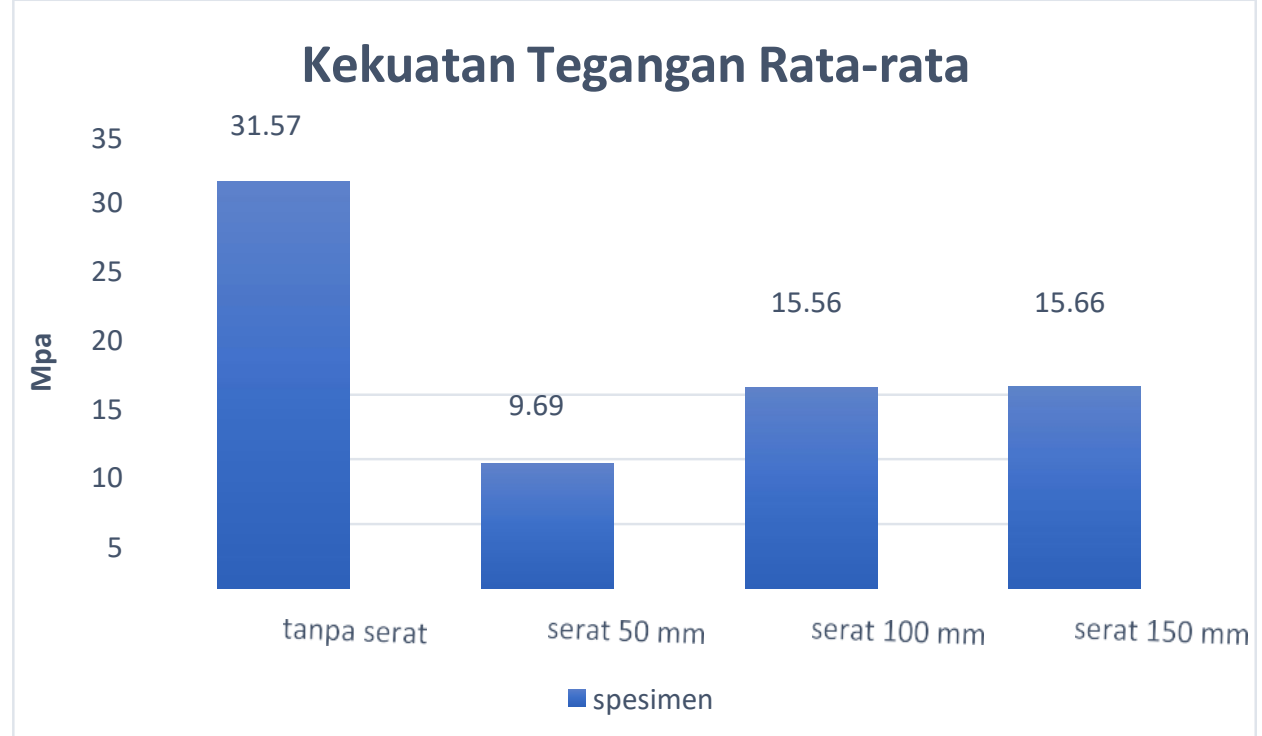

Gambar 3. Grafik $\sigma$ (Kekuatan Regangan)

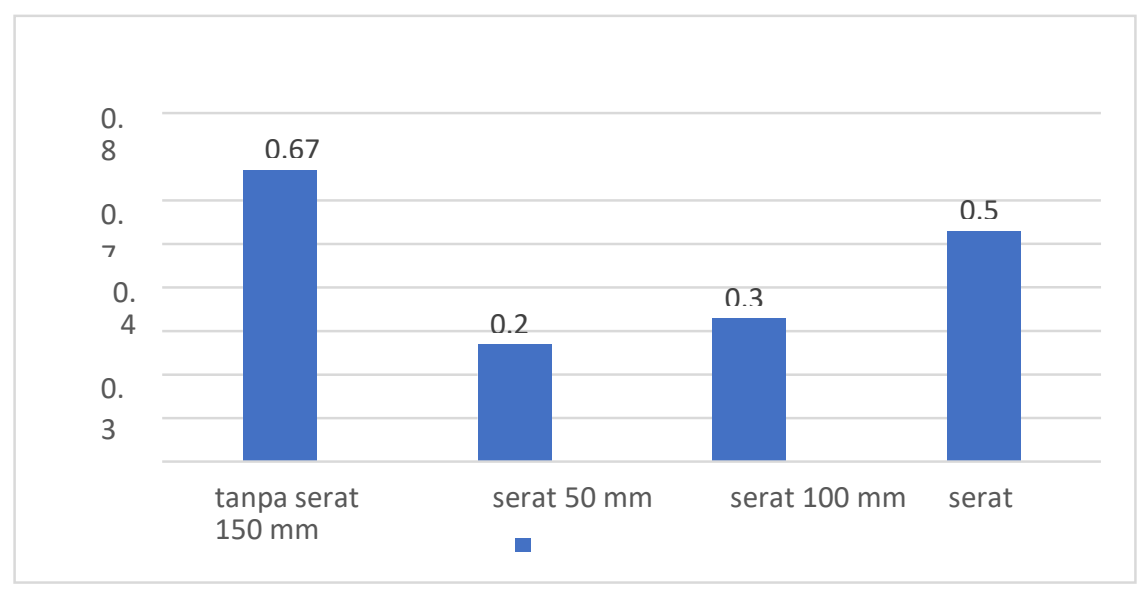

Gambar 4 Grafik \& (Regangan)

1) Nilai maksimun rata-rata regangannya $0,53 \%$ dengan serat panjang serat $150 \mathrm{~mm}$, dengan komposisi resin 60\% dan serat $40 \%$.

2) Nilai maksimum dari komposit berpenguat serat daun nanas 15,66 Mpa, dengan panjang serat $150 \mathrm{~mm}$.

3) Resin dengan serat nanas kurang melekat, sehingga adanya udara di selasela serat.

4) Panjang serat berpengaruh pada material komposit karena di setiap spesimen terjadi putus di sambuangan serat.

5) Kekuatan Tarik pada bumper mobil, dengan standar Japan Indistrial Standar (JIS) A5905 - 2003, adalah sebesar 0,4 Mpa dan data hasil dari 
pengujian Tarik serat nanas dengan panjang serat $150 \mathrm{~mm}$ didapatkan 15,66 Mpa sehingga memenuhi standar untuk pembuatan bumper mobil [6].

\section{b. Pengujian Impak}

Dari hasil pengujian yang dilakukan dengan variasi yang berbeda- beda, didapatkan hasil energi yang paling tinggi ada pada komposit dengan panjang serat $100 \mathrm{~mm}$ dengan energi 13,41 joule dan hasil dari harga impack tertinggi ada pada komposit dengan panjang serat 100mm dengan harga impack 0,146 joule. Dari hasil tersebut menunjukkan penambahan fraksi semakin rapat susunan serat didalam komposit menimbulkan nilai serat dan nilai kekuatannya semakin meningkat, hal ini dikarenakan gaya yang diterima oleh matrik akan diteruskan keserat penguatnya. Dari masing- masing lapisan serat diambil rata-rata dari energi dan harga impack. Nilai rata-rata yang diperoleh terdapat pada Gambar 5 dan Gambar 6.

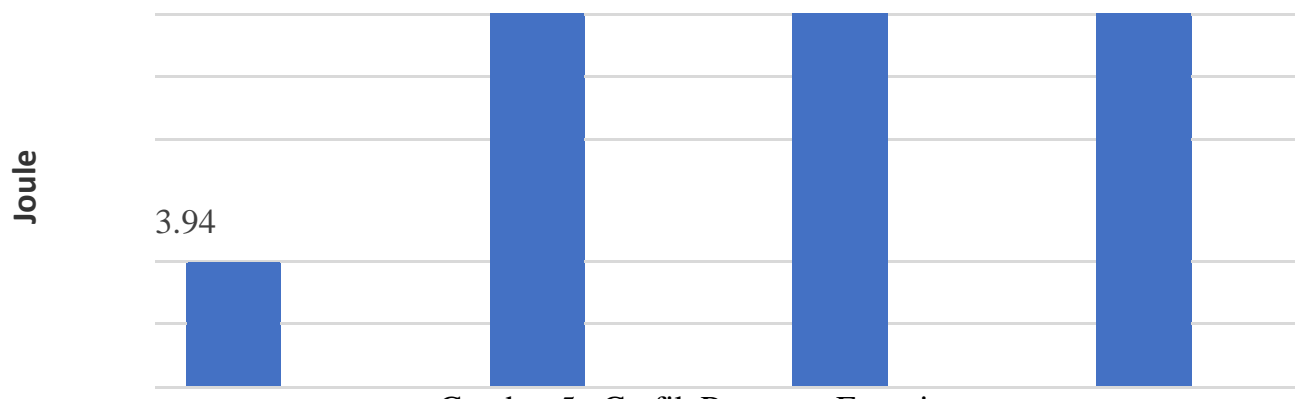

Gambar 5. Grafik Rata-rata Energi

Perhitungan Energi Impack teroritis besarnya energi Impack (Joule) dapat dilihat pada skala mesin penguji. Sedangkan besarnya energi Impack dapat dihitung. Hukum Kekekalan Energi, yang mengatakan bahwa jumlah energi mekanik konstan.

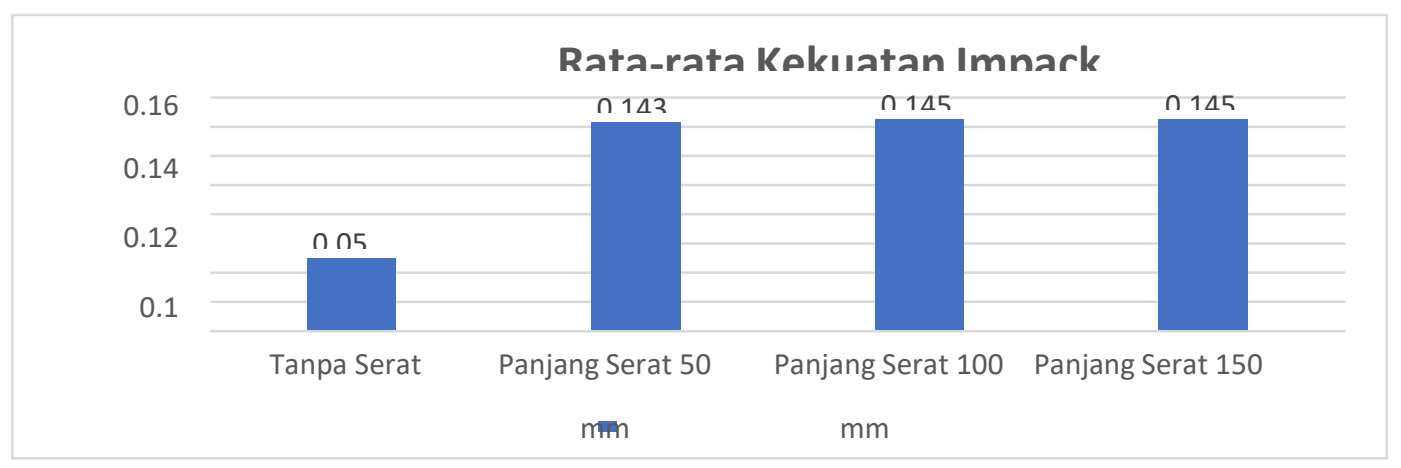

Gambar 6. Grafik Rata-rata Kekuatan Impack

Dari hasil pengujian yang dilakukan dengan variasi yang berbeda-beda, 
didapatkan hasil energi terserap rata-rata yang paling tinggi ada pada komposit dengan panjang serat $100 \mathrm{~mm}$ dengan serapan energi sebesar 11,23 joule dan hasil dari harga impack tertinggi ada pada komposit dengan panjang serat $100 \mathrm{~mm}$ dan $150 \mathrm{~mm}$ dengan harga impack $0,145 \mathrm{~J} / \mathrm{mm} 2$

Dari hasil rata-rata tersebut diketahui bahwa penjang, pemakaian serat, serta kerapatan serat sangat berpengaruh besar dalam pengujian impack. Dari grafik yang ditampilkan pada Gambar 5 dan Gambar 6 ini dapat dianalisis beberapa hal diantaranya adalah:

1) Hasil Energi rata-rata yang paling tinggi ada terdapat pada komposit dengan pajang serat $100 \mathrm{~mm}$ dengan energi 11,23 joule dan hasil kekuatan impack tertinggi ada pada komposit dengan panjang serat $100 \mathrm{~mm}$ dan $150 \mathrm{~mm}$ dengan harga impack 0,145 J/mm2 (dengan dimensi serat $60 \mathrm{~mm} \times 10 \mathrm{~mm}$ x $10 \mathrm{~mm}$ dan prosentase volume serat $40 \%$ ).

2) Hasil patahan dari masing-masing komposit berbeda-beda, jika takikan terdapat serat, maka patahanya masih menyambung.

3) Dengan panjang $100 \mathrm{~mm}$ dan $150 \mathrm{~mm}$ memiliki kekuatan impack yang sama, sehingga menunjukan bahwa variasipanjang serat tidak terlalu berpengaruh terhadap uji impack karena didapatkan hasil yang tidak terlalu berbeda pada tiap variasinya di karenakan benda uji memliki panjang $60 \mathrm{~mm}$ jadi disetiap benda uji tidak memiliki sambungan serat karena panjang seratnya $50 \mathrm{~mm}$, 100, dan $150 \mathrm{~mm}$.

4) Kekuatan Impack pada bumper mobil stamdar Japan Industrial Standar (JIS) A5905-2003 adalah 0,02433 J/mm2, dan hasil dari pengujian impack komposit berpnguat serat daun nanas didapatkan nilai sebesar $0,145 \mathrm{~J} / \mathrm{mm} 2$, ehingga memenuhi standar pembuatan bumper mobil.

\section{KESIMPULAN}

Berdasarkan hasil penelitian yang telah dilakuakan dan dianalisa maka didapatkan kesimpulan sebagai berikut:

a. Sifat mekanik komposit berpenguat serat daun nanas dengan panjang serat 50 mm kekuatan Tarik sebesar 9,69 Mpa, regangan sebesar 0,27 \% dan energi Impack 10,14 joule, harga Impack sebesar 0,143 J/mm2.

b. Sifat mekanik komposit berpenguat serat duan nanas dengan panjang serat 100 
mm kekuatan Tarik sebesar 15,56 Mpa, regangan sebesar 0,33\% dan energi impack 11,23 joule, kekuatan Impack sebesar 0,145 J/mm2.

c. Sifat mekanik komposit berpenguat serat daun nanas dengan panjang serat 150 mm kekuatan Tarik sebesar 15,66 Mpa, regangan sebesar 0,53\% dan energi Impack sebesar 10,14 joule, kekuatan Impack sebesar 0,145 J/mm2

d. Komposit dengan variasi panjang serat berpengaruh terhadap kekuatan tegangan dan regangan ini bisa dilihat dengan panjang serat $150 \mathrm{~mm}$ memiliki nilai tegangan yang tinggi di banding dengan panjang serat 50mm dan 100 $\mathrm{mm}$.

e. Sifat mekanik komposit dengan tegangan Tarik dan regangan Tarik tertinggi adalah komposit dengan panjang serat $150 \mathrm{~mm}$. sedangakan sifat mekanik komposit dengan energi Impack dan kekuatan Impack hampir tidak jauh berbeda pada setiap spesimennya karena setiap spesimen tidak memiliki sambungan serat pada setiap spesimen sehinnga speismen masih menyambung/tidak putus di setiap takikan setelah pengujian impack

f. Terbentuk komposit serat daun nanas dengan biaya yang murah dan berpotensi sebagai bahan pembuatan bumper mobil karena sudah memenuhi standar JIS A5905-2003.

\section{DAFTAR PUSTAKA}

[1] Brower, W.D. 2020. Natural Fibre Composites In Structural Components, Alternative For Sisal. On ThOccasion Of The Joint FAD, CFC Seminar, Rome Italy.

[2] Dinpertan. $2018 . \quad$ Budidaya Nanas Madu. https://dinpertan.purbalinggakab.go.id/budidaya-nanas-madu/

[3] Jayanudin. 2009. Pemutihan Daun Nanas Menggunakan Hidrogen Peroksida. Jurnal Rekayasa Proses, Vol. 3, No. 1.

[4] Nuri, S.H, Suwanda, T., Diharjo, K., A Amin. S. 2006. Kinerja Komperhensif Pengaruh Perlakuan Alkali Terhadap Kekuatan Komposit Berpengaut Serat Nanas-Nanasan. Laporan penelitian Dosen Muda. Jakarta: Direktorat Jendral Pendidikan Tinggi. Departemen Pendidikan Nasional

[5] Yanuar D., dan Diharjo K., "Karakteristik Mekanis Komposit Sandwich Serat Gelas Serat Chopped Strand Mat Dengan Penambahan Lapisan Gel Coat", Skripsi, Teknik Mesin FT UNS, Surakarta.

[6] Yukichi F. 2003. Japanese Industrial Standart. JIS A 5905: 2003 Fiberboard. Translated and Published by Japanese Standards Association 